\title{
The Impact of Frayer Model and Contextual Redefinition strategy on Improving Preparatory Stage Pupils' Vocabulary Learning
}

\author{
Sara Albadawy Abdel-Naby Alashry
}

A teacher of English

Dr. Aly Abdel-Samea Qoura

Professor of Curriculum\& Instruction: TEFL

Dr.Rehab Hamadtoh Abu-Alghait Gohar

Lecturer of Curriculum\& Instruction: TEFL

\section{Abstract}

The current study aimed at improving vocabulary
learning of the preparatory stage pupils by using
Frayer Model and Contextual Redefinition strategy. The study adopted a quasi-experimental design employing three groups (two experimental groups and a control group). One instrument was used which was a vocabulary learning test. The sample consisted of 75 pupils from second year preparatory school of Mahmoud Shehab Preparatory school, in Dakahlia Governorate, where 25 pupils represented the first experimental group, 25 pupils represented the second experimental group, and 25 pupils represented the control group. The Frayer Model was administered to the first experimental group and Contextual Redefinition strategy was administered to the second experimental group for six weeks. Results of the study revealed that there is a statistically significant difference between the mean scores of the two experimental groups and the control group in the post-test of the VLT. In addition, there is a statistically significant difference between the mean scores of the pre-test and post-test of the first experimental group and the second experimental group in the overall VLT in favor of the post-test. These results showed that Contextual Redefinition strategy had a positive effect on the pupils' vocabulary learning. Finally, a number of recommendations related to the use of Frayer Model and Contextual Redefinition strategy, vocabulary learning and teaching, and course design were presented.

Keywords: frayer model, contextual redefinition strategy, vocabulary learning. 


\section{Introduction:}

With the increasing communication of economy and culture between countries, the importance of English is recognized more and more. Therefore, English has been taught in Egyptian schools for a long time.

Vocabulary is an important skill in English, it plays a great role in teaching and learning English. Vocabulary is a crucial element to master the four language skills speaking, listening, reading and writing. Learners who are rich of vocabulary will be capable of expressing their feeling, ideas and thoughts in English. But those who are poor of vocabulary will have problems in other skills. So, without vocabulary students cannot achieve language skills. Greenwood (2002) mentioned that Readers comprehend and learn when they are able to connect the new information in their reading material to what they already know. Vocabulary instruction, therefore, should help students make the connections between unknown words and the knowledge they already possess.

Vocabulary is central to language and it has a great significance to language learners. Words are the building blocks of a language since they label objects, actions and ideas without which people cannot convey the intended meaning. It has been suggested that teaching vocabulary should not only consist of teaching specific words but also aim at equipping learners with strategies necessary to expand their vocabulary knowledge (Hulstjin,1993, cited in Morin \& Goebel, 2001).

Vocabulary is defined as the whole stock of words belonging to a branch of knowledge or familiar by an individual. Also, a single unit of language conveys meaning on its own and is not a portion of any linguistic pattern that might change the word's meaning with reference to other words (Graves, 2007).

Vocabulary is the knowledge of words and word meanings. Stahl (2005) puts it, "Vocabulary knowledge is; the knowledge of 
a word not only implies a definition, but also implies how that word fits into the world." (pp.95-114). Learning vocabulary is a main part of mastering a second language (Schmitt, 2008). Stahl and Kapinus (2001) indicated that when children 'be familiar with' a word, they not only know the word's definition and its reasonable relationship with other words, they also know the functions of a word in different contexts.

Vocabulary has a crucial part in understanding and producing language, therefore, it is important to learn vocabulary when learning a foreign language (Read, 2000). Vocabulary is a crucial element in language learning, since Vocabulary plays an important role in expressing feelings, emotions, and ideas to others during communication. Therefore, without the intervention of vocabulary, the amount of grammatical or other types of linguistic knowledge cannot be employed in foreign language communication. Vocabulary is central to language and it has a great significance to language learners in order to convey the intended meaning. According to Read (2000), words are considered as the basic building unit of language. Also, the larger structures such as sentences, paragraphs and the whole text are created by the words.

Al Neyadi (2004) claim that, vocabulary plays a great role in the development of the four language skills: speaking, listening, reading and writing. Folse (2008) reported that English language learners need a solid knowledge of vocabulary in order to develop their language proficiency. Also, he added that while students acquire more vocabulary, this will make their communication and sharing ideas more better.

Kucan (2012) explained that Students require vocabulary teaching that allows them to build rich representations of words. So, teachers need to plan and implement vocabulary lessons that can help students in developing the kind of high-quality lexical representations that will continue and be available for reading and writing. 
Vocabulary can be expanded through cooperative learning such as other language learning skills. Gu (2003) pointed out that vocabulary acquisition is a very learner-centered activity with the effectiveness of the learner's strategies depending on his/her attitude and motivation towards new vocabulary acquisition. This is true because the main motivational learning factor must come from the student, but when learning vocabulary in a cooperative learning environment it allows students to learn from peers closest to them. Murphey and Arao (2001) pointed out that students felt more relaxed and learned more from peers since they saw that making mistakes is acceptable, having goals is good, and learning English can be fun.

\section{Frayer model}

A number of strategies have been used to help students learning vocabulary such as (Graffiti Vocabulary, Making Meaning, Word Wall Match-Up and semantic mapping). Amongst these vocabulary learning strategies Frayer Model and Contextual Redefinition Strategy.

Through Frayer Model's students are able to understand not only the meaning of an unknown word or concept, but more importantly, they will be able to internalize the word or concept so that it becomes part of their everyday vocabulary. The chart of Frayer Model consists of four squares to complete definition, characteristics, examples, and non-examples and an oval in the center for the word or concept being studied. The Frayer Model is a graphical organizer used for word analysis and vocabulary building. This four-square model prompts students to think about and describe the meaning of a word or concept by defining the term, describing its essential characteristic, providing examples of the idea, and offering non-examples of idea.

Teacher Resource guide (2006) used the frayer model in vocabulary instruction encourages students to use critical thinking to identify and understand vocabulary that is not familiar to them. This strategy also helps students build connections between new concepts and helps students move beyond vocabulary exercises that are simply about words and 
their meanings to grasping how to use new ideas and concepts in context.

Frayer model is a technique for teaching vocabulary, essentially a type of graphic organizer that allowed the students to separate the various aspect of a word or concept. Frayer Model is used to identify and define unfamiliar concepts and vocabulary. For every word, Frayer model asks students to write down a definition and lists of characteristics, examples, and nonexample (Tankersley,2005).

Nahampun\& Sibarani (2014) investigated Using this model helps students develop a conceptual understanding of new vocabulary or concept. Using this particular graphic organizer helps students to think about this term in a variety of ways. It allows them to visually demonstrate what they understand and to categorize their new knowledge. This can also serve as a great tool for review or as a study aid. Additionally, by using Frayer model in learning vocabulary continuously, student's memorization of word will be affected become long term memory. With the long term memory of words, student's vocabulary achievement will be increased. Therefore, it can be assumed that using Frayer Model method will improve students' mastery in vocabulary.

WETA (2012) showed that this technique requires students to (1) define the target vocabulary words or concepts, and (2) apply this information by generating examples and nonexamples. The information is placed on a chart that is divided into four sections to provide a visual representation for students. This instructional strategy promotes critical thinking and helps students to identify and understand unfamiliar vocabulary. The Frayer Model can be used with the entire class, small groups, or for individual work. The Frayer Model draws on a student's prior knowledge to build connections among new concepts and creates a visual reference by which students learn to compare attributes and examples. 
The Frayer model (Frayer, Frederick, and Klausmeier, 1969) helps students learn new concepts through the use of attributes and non-attributes. It is recommended for very important and probably new and complex words only (Greenwood, 2007). Frayer et al. (1965) tried to use concept based on Bourne's definition, claiming that a concept exists whenever two or more distinguishable objects or events have been grouped or classified together and set apart from objects on the basis of some common feature or property of each.

Furthermore, Macceca (2007) showed that the Frayer Model is a strategy in which students use the graphic organizer as a mean to better understand a concept and to distinguish that concept from others.

\section{Contextual Redefinition Strategy}

\section{Context clues}

Context clues are clues to the meaning of a word that are contained in the text and illustrations that surround it. Context clues can include definitions, examples, and restatements, as well as charts, pictures, and type features.

Greenwood and Flanigan (2007) stated that children learn approximately 4,000 words in a school year, but that only 400 of them are learned through direct instruction. If, on average, $90 \%$ of the words are learned through repeated, meaningful encounters then this avenue of learning should be optimized. Also, they discussed that context clues merit careful teaching and students need to realize that authors choose their words carefully and purposefully.

$\mathrm{Gu}$ (2003) stated that learning new words through context is only one step students may use, and that students should think meta-cognitively and learn new words within the context of where they appear. To help the student, learn the important words from the context of a lesson, a teacher needs to focus on low context words, which necessitates a second distinction: high frequency and low frequency words. 
Contextual analysis helps students learn to predict and verify word meaning of unfamiliar words or familiar words that have new/unusual meanings. Students search for clues in nearby words, sentences, and paragraphs of a text. Specific context clues that should be explicitly taught are definition/explanation, synonym/restatement, antonym/contrast, inference/general, and punctuation context. Learning to use context clues is a skill that develops over time with students practicing this skill with multiple print and digital texts in diverse media, formats, and lengths (Frey\& Fisher, 2009).

Contextual Redefinition (Cunningham, Cunningham, and Arthur 1981) is a teaching strategy that helps students learn the importance of context clues in understanding the meaning of a word or concept. Contextual Redefinition provides a way to introduce new vocabulary words to your students and gives students the opportunity to use a variety of context clues to predict and verify meanings. While context clues, when used alone, are not often a reliable source of word meaning (Shatz and Baldwin 1986; Nagy, Herman, and Anderson 1985; Deighton 1959), knowing how and when to use the clues that are in the text is a critical step toward students independently increasing their vocabulary. Contextual redefinition, it is a strategy that emphasizes the importance of context in predicting and verifying word meaning (Tierney et al., 1985).

This instructional strategy is appropriate for teaching students how to use context clues and definitions to solidify knowledge of word meanings. It would be appropriate to use this type of strategy every few weeks with a new novel or unit of study. This activity provides opportunities or students to predict word meanings and practice using each of the types of context clues to determine word meaning.

Therefore, the purpose of this study was to investigates the impact of these individual strategies on enhancing $2^{\text {nd }}$ year preparatory stage pupils' vocabulary learning. 


\section{Review of literature}

A number of researches had been done on investigating the relationship between Frayer Model and Vocabulary learning.

\section{Frayer Model and Vocabulary learning}

A number of studies had been carried out to evaluate, discuss or measure the value of Frayer Model in teaching and learning vocabulary.

Billmeyer (2003) concluded that Frayer model can be used as a strategy that enhances learning of vocabulary in all content areas. Teachers identify the critical words students need to know in order to understand a concept.Teachers from all content areas find this strategy very beneficial. For example 'critical words for the concept of photosynthesis: chlorophyll, cells, chemical energy, and oxygen.

Febriyanto (2010) concluded that using Frayer model in learning vocabulary facilitates the students to understand the words in which they can build connection between their prior knowledge and new information to extend their vocabulary from those words by completing the components of Frayer model. Also the use of Frayer model in extending vocabulary makes the students motivated, interested. It can be created or varied by using pictures in the middle of box. It will show how students can think critically about a topic.

Nahampun\& Sibarani (2014) investigated the effect of using Frayer Model on students' vocabulary mastery. The researcher used the experimental design. The sample of this study was sixty students of first grade senior high school. The researcher concluded that there is a significant effect of using Frayer Model on Students' Vocabulary Mastery since the students' mastery in vocabulary by using Frayer Model is higher than those taught without using Frayer Model (by conventional Method).

Mardiyah (2014), Frayer Model significantly improved the students' achievement in vocabulary mastery. This study was conducted by using classroom action research. The sample of this 
research was the seven grade of SMP Negeri which consisted of 32 students. The research was conducted in two cycles that consist of six meetings. The instruments for collecting the primary data was taken from the students' score in vocabulary mastery and the instruments for collecting the secondary data were observation sheet, interview sheet, and questionnaire sheet.

Sullivan (2014) investigated the use of an adapted Frayer model as a graphic organizer to improve the vocabulary comprehension of Japanese university students. The Frayer model was adapted to explain graph vocabulary, which is less concrete than the language the model was originally used for. Results indicated that the model was helpful in understanding and applying graph vocabulary. The adapted Frayer model addresses productive and receptive aspects (of form, meaning, and use) involved in knowing a particular graph term than the original one did. The researcher concluded that the adapted Frayer model saves learners time and effort by neatly compiling valuable implicit and explicit information about an abstract graph word related to several productive and receptive aspects of form, meaning, and use on a single card.

\section{Contextual Redefinition Strategy and Vocabulary learning}

Khuwaileh (1995) investigated the effect of contextualization techniques on vocabulary learning of the intermediate-level Jordanian university students $(\mathrm{N}=40)$. There were two lists, each containing twenty new words. List one was presented with English meaning and discussed in Arabic, the words of list two were in a text for silent reading with vocabulary questions. After 12 weeks, the students were tested on both groups of words. The results showed a clear advantage of contextualization for comprehension, learning and recall.

Abd Alkader (2007) studied the effectiveness of instruction in context clues in improving EFL students' ability to derive word 
meaning from context and their reading comprehension. The instruments of the study were two tests to measure the ability to derive word meaning from context and a reading comprehension test. The results of the study revealed that the two groups were not significantly different either in the ability to derive word meaning from context or in reading comprehension. Also, results indicated that instruction in context clues not only improve EFL university students' ability to derive word meaning from context, but also enhances their reading comprehension.

A study conducted by Kelley, Lesaux, Kieffer, and Faller (2010) at seven middle schools in an urban setting focused on determining if students' reading comprehension skills could be boosted by implementing a regular, systematic instruction of academic vocabulary. To determine this, researchers developed a vocabulary program that followed three guiding principles: first, educators will focus on a deeper understanding of fewer words; second, educators will choose words that are academic words and help to deliver the content to the reader; third, educators will use direct instruction and word-learning strategies in equal amounts. The study was designed to last 18 weeks. Researchers found students in the test group had greater gains than the control group on standardized and researcher-developed measures of vocabulary, word learning, and comprehension. This vocabulary program really focused on the less-is-more theory and is believed to help prepare students to use the vocabulary strategies they will need to be successful in high school.

Soureshjani and Rashidi (2011) indicated the the effects of two vocabulary teaching techniques (contextualization and decontextualization techniques) on the elementary Iranian EFL learners. To achieve such a purpose, 190 male and female language learners were randomly selected and assigned into two groups, a control group and an experimental group. In the control group, the new English words were presented in word lists associated with their Persian meanings and students were supposed to memorize them (a decontextualizing technique). In the other group, the new English words were presented in model 
sentences (a contextualizing technique). The data were collected using two reliable and valid tests as pretest and posttest: Each of them consisted of 15 equivalent multiple-choice items of vocabulary. The result of the study revealed significant differences between the two groups of the study. The experimental group outperformed those in the control group quite significantly on vocabulary memorization test. The experimental group also had a better performance on a sentencemaking test than the control group though the differences were not significant. The results showed that contextual redefinition is effective in enhancing students' vocabulary development.

Wiese (2012), investigated which two vocabulary strategies, Verbal and Visual Word Association or Contextual Redefinition, was best suited for transferring new words into students' long-term memory. The study first looked at the current vocabulary strategy/strategies used with a test group of 52 ninth grade students from an upper Midwestern school. The researcher then taught and used the Verbal and Visual Word Association strategy with the same 52 students. Finally, the Contextual Redefinition strategy was taught and data was analyzed. The results of the study indicated the students who used the Verbal and Visual Word Association strategy transferred vocabulary words to their long-term memories at a slightly higher rate than when those same students used the Contextual Redefinition strategy.

In her study, Qasrawi (2015) examined the effectiveness of using context clues strategy in developing students' vocabulary knowledge. It also studied the effectiveness of the strategy in equipping students with tools that they might use in inferring the unknown words' meaning from the context. The study followed the quasi-experimental design methodology. The sample assigned randomly into two groups (experimental and control). The experimental group was taught using the context clues teaching strategy whereas the control group was taught the same list of vocabulary following the individual words strategy. The test was the instrument of the study. The results revealed a 
significant difference between the experimental and control group in the post-test total score. It was concluded that context clues teaching strategy enhanced students' vocabulary knowledge. Students showed an improvement in their ability in inferring the meaning of the unknown words.

Another study conducted by Al Hussona (2016) investigating the effect of some context clues in teaching vocabulary on Iraqi EFL university students' achievement. The researcher concluded that learning vocabulary through context might be effective in increasing students' vocabulary knowledge. Also, the researcher added that the exposure to words in context is preferable to exposure to words in isolation. The results of the study proved that the students in experimental group outperformed than the control ones.

Therefore, this study aimed to investigate how teachers can effectively incorporate the Frayer Model and Contextual Redefinition strategy into EFL classroom with the purpose of improving learners' vocabulary learning, using Frayer Model and Contextual Redefinition strategy that have a positive effect on pupils' vocabulary learning.

\section{Pilot study}

In order to provide evidence for the problem of the study, the researcher conducted a pilot study to determine pupils' vocabulary level. The test was applied to a sample of 40 second year preparatory stage pupils at Mahmoud Shehab Preparatory school.

Table (1) students Mean score on the VLT

\begin{tabular}{|l|l|l|l|}
\hline $\mathbf{N}$ & Maximum scores & Mean & Percentage \\
\hline $\mathbf{4 0}$ & $\mathbf{3 0}$ & $\mathbf{1 2 . 4 5}$ & $\mathbf{4 1 . 5 0}$ \\
\hline
\end{tabular}

Results in table (1) indicates that the mean score of the sample is (12.45) which is very low so, students need improvement in vocabulary learning.

\section{Statement of the Problem:}

Based on the literature review and the related studies, researcher's experience as a teacher of English and results of the 
pilot study, it is evident that students are not able to comprehend and use vocabulary appropriately. This, in turn, may affect their EFL learning, the problem can be stated as follows:

Second year preparatory stage pupils' have many difficulties in mastering new words so, the current study will investigate the impact of Frayer Model and Contextual Redefinition strategy to enhance their vocabulary learning.

\section{Questions of the Study}

1. What are the vocabulary types that are necessary for $2^{\text {nd }}$ year prep stage pupils'?

2. What are the components of Frayer Model to enhance $2^{\text {nd }}$ year prep stage pupils' vocabulary learning?

3. What are the steps of Contextual Redefinition strategy to enhance $2^{\text {nd }}$ year prep stage pupils' vocabulary learning?

4. What is the effectiveness of Frayer Model in enhancing $2^{\text {nd }}$ year prep stage pupils' vocabulary learning?

5. What is the effectiveness of Contextual Redefinition strategy in enhancing $2^{\text {nd }}$ year prep stage pupils' vocabulary learning?

\section{Purpose of the study}

\section{The current study aims at}

1. Introducing Frayer model for enhancing vocabulary learning of the $2^{\text {nd }}$ year preparatory stage students'.

2. Measuring the impact of Frayer model strategy and Contextual Redefinition in enhancing vocabulary learning of the $2^{\text {nd }}$ year preparatory stage students'.

3. Improving $2^{\text {nd }}$ year preparatory stage students' vocabulary leaning through Contextual Redefinition strategy.

\section{Hypotheses of the study}

1. There is a statistically significant difference at $\leq 0.05$ level between the mean score of the three groups (control, first 
experimental and the second experimental groups) on the post administration of the vocabulary learning test.

2 . There is a statistically significant difference at $\leq 0.05$ level between the mean score of the pre-post administration of the vocabulary learning test to the control group.

3. There is a statistically significant difference at $\leq 0.05$ level between the mean score of the pre-post administration of the vocabulary learning test to the first experimental group in favor of the post administration of the first experimental group.

4. There is a statistically significant difference at $\leq 0.05$ level between the mean score of the pre-post administration of the vocabulary learning test to the second experimental group in favor of the post administration of the second experimental group.

\section{Delimitations}

This study will be delimited to:

1. A sample of second year preparatory stage pupils' (males and females) of Mahmoud Shehab preparatory school in Bossat Kariem El-Deen.

2. Frayer Model and contextual redefinition strategy.

3. Several units needed for second year preparatory stage students to improve their vocabulary learning.

\section{Design of the study}

The present study adopted the quasi-experimental design using three groups. One group was the control who was taught the vocabulary of English language book of the $2^{\text {nd }}$ year preparatory stage (Hello!), first term from unit 1 to 4 and unit 9 through the regular method. The second group was the first experimental group who was taught the same vocabulary through Frayer Model. The third group was the second experimental group who was taught the same vocabulary through Contextual Redefinition strategy.

This design included the following variables: two independent variables which were Frayer Model and Contextual 
Redefinition strategy and a dependent variable which was vocabulary learning. The following figure shows the design of this study:

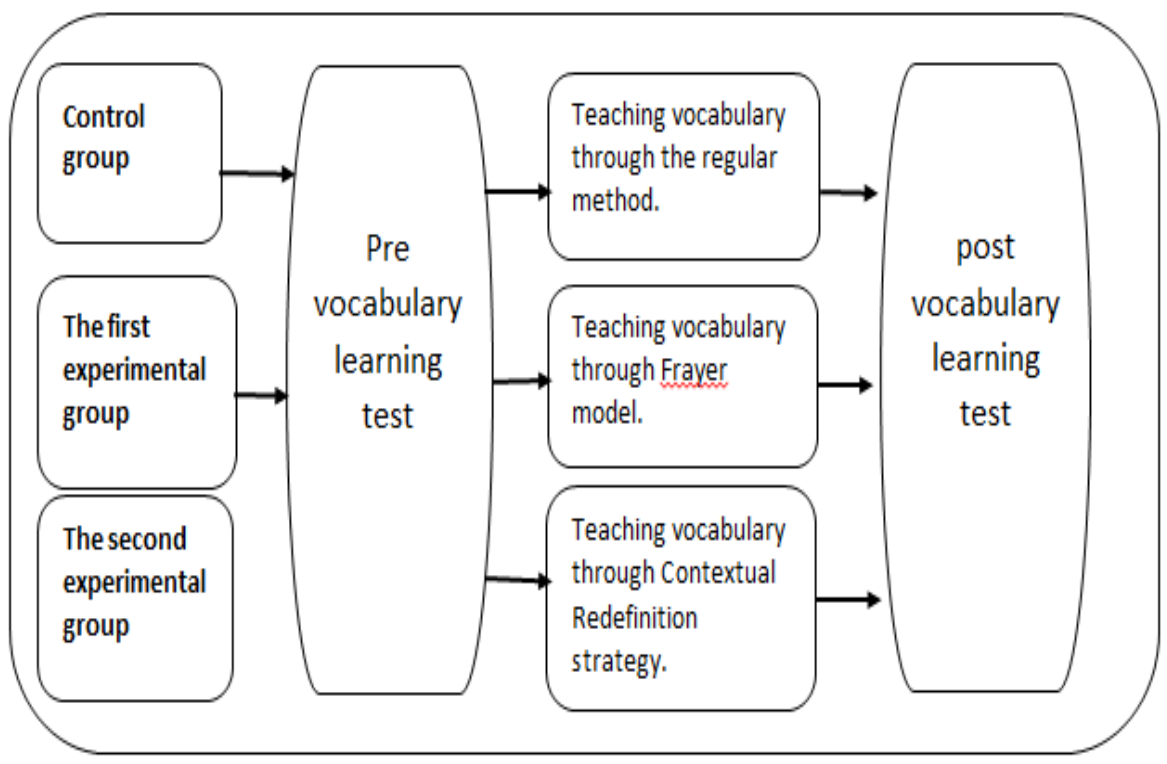

Figure (1): Design of the Study

\section{Instrument of the Study}

To achieve the aims of the current study, the following instrument was used: Pre- post Vocabulary Learning Test (VLT) to measure students' vocabulary learning before and after the treatment.

\section{Results and discussions}

Results were statistically analyzed in terms of the hypotheses. They were discussed in the light of the theoretical background and related studies. Results of the study were separated according to the hypotheses

\section{Results Related to the first Hypothesis}

Concerning the differences among the three groups on the VLT results showed that the two experimental groups 
outperformed the control group. Table (2) and (3) illustrated these results.

Table (2): Differences among the Three groups in the Post Vocabulary Test Score

\begin{tabular}{|c|c|c|c|c|c|c|}
\hline Items & Groups & $\begin{array}{l}\text { Sum of } \\
\text { Squares }\end{array}$ & df & $\begin{array}{l}\text { Mean } \\
\text { Square }\end{array}$ & $\mathbf{F}$ & Sig. \\
\hline \multirow[t]{3}{*}{ QA } & $\begin{array}{l}\text { Between } \\
\text { Groups }\end{array}$ & 20.160 & 2 & 10.080 & 5.223 & .008 \\
\hline & $\begin{array}{l}\text { Within } \\
\text { Groups }\end{array}$ & 138.960 & 72 & 1.930 & & \\
\hline & Total & 159.120 & 74 & & & \\
\hline \multirow[t]{3}{*}{ QB } & $\begin{array}{l}\text { Between } \\
\text { Groups }\end{array}$ & 127.040 & 2 & 63.520 & 20.918 & .000 \\
\hline & $\begin{array}{l}\text { Within } \\
\text { Groups }\end{array}$ & 218.640 & 72 & 3.037 & & \\
\hline & Total & 345.680 & 74 & & & \\
\hline \multirow[t]{3}{*}{ QC } & $\begin{array}{l}\text { Between } \\
\text { Groups }\end{array}$ & 86.960 & 2 & 43.480 & 14.800 & .000 \\
\hline & $\begin{array}{l}\text { Within } \\
\text { Groups }\end{array}$ & 211.520 & 72 & 2.938 & & \\
\hline & Total & 298.480 & 74 & & & \\
\hline \multirow[t]{3}{*}{ QD } & $\begin{array}{l}\text { Between } \\
\text { Groups }\end{array}$ & 149.227 & 2 & 74.613 & 18.747 & .000 \\
\hline & $\begin{array}{l}\text { Within } \\
\text { Grouns }\end{array}$ & 286.560 & 72 & 3.980 & & \\
\hline & Total & 435.787 & 74 & & & \\
\hline \multirow[t]{3}{*}{$\overline{\mathbf{Q E}}$} & $\begin{array}{l}\text { Between } \\
\text { Groups }\end{array}$ & 167.707 & 2 & 83.853 & 31.289 & .000 \\
\hline & $\begin{array}{l}\text { Within } \\
\text { Groups }\end{array}$ & 192.960 & 72 & 2.680 & & \\
\hline & Total & 360.667 & 74 & & & \\
\hline \multirow[t]{3}{*}{$\mathbf{Q F}$} & $\begin{array}{l}\text { Between } \\
\text { Groups }\end{array}$ & 271.787 & 2 & 135.893 & 31.280 & .000 \\
\hline & $\begin{array}{l}\text { Within } \\
\text { Groups }\end{array}$ & 312.800 & 72 & 4.344 & & \\
\hline & Total & 584.587 & 74 & & & \\
\hline \multirow[t]{3}{*}{$\begin{array}{l}\text { Total } \\
\text { post }\end{array}$} & $\begin{array}{l}\text { Between } \\
\text { Groups }\end{array}$ & 4283.387 & 2 & 2141.693 & 39.602 & .000 \\
\hline & $\begin{array}{l}\text { Within } \\
\text { Groups }\end{array}$ & 3893.760 & 72 & 54.080 & & \\
\hline & Total & 8177.147 & 74 & & & \\
\hline
\end{tabular}

Results of ANOVA show that there is a statistically significant difference between the mean score of the three groups (control, first experimental and the second experimental groups) on the post administration of the vocabulary learning test. Calculated F was 5.223, 20.9, 14.8, 18.7, 31.2, 31.2, and 39.6 
respectively in the sub-questions and the total score of the vocabulary learning test which indicated that there is a difference between the three groups in the vocabulary learning post test.

To determine the direction of differences, the researcher used Post-Hoc Multiple Comparison between mean scores by Scheffe Method. See the results in table (3).

Table (3): Direction of Differences among the Three Groups on the Post Administration of the Vocabulary Learning Test.

\begin{tabular}{|c|c|c|c|c|c|}
\hline Item & Group & Mean & Control & $\begin{array}{l}\text { First } \\
\text { Experimental }\end{array}$ & $\begin{array}{l}\text { Second } \\
\text { Experimental }\end{array}$ \\
\hline \multirow[t]{3}{*}{$\overline{\mathbf{Q A}}$} & Control & 8.56 & - & $*$ & * \\
\hline & $\begin{array}{l}\text { First } \\
\text { Experimental }\end{array}$ & 9.52 & - & - & - \\
\hline & $\begin{array}{l}\text { Second } \\
\text { Experimental }\end{array}$ & 9.76 & - & - & - \\
\hline \multirow[t]{3}{*}{ QB } & Control & 3.92 & - & * & * \\
\hline & $\begin{array}{l}\text { First } \\
\text { Experimental }\end{array}$ & 6.64 & - & - & - \\
\hline & $\begin{array}{l}\text { Second } \\
\text { Experimental }\end{array}$ & 6.72 & - & - & - \\
\hline \multirow[t]{3}{*}{$\mathbf{Q C}$} & Control & 4.92 & - & $*$ & $*$ \\
\hline & $\begin{array}{l}\text { First } \\
\text { Experimental }\end{array}$ & 7.28 & - & - & - \\
\hline & $\begin{array}{l}\text { Second } \\
\text { Experimental }\end{array}$ & 7.12 & - & - & - \\
\hline \multirow[t]{3}{*}{ QD } & Control & 3.8 & - & * & * \\
\hline & $\begin{array}{l}\text { First } \\
\text { Experimental }\end{array}$ & 5.80 & - & - & * \\
\hline & $\begin{array}{l}\text { Second } \\
\text { Experimental }\end{array}$ & 7.24 & - & - & - \\
\hline \multirow[t]{3}{*}{$\mathbf{Q E}$} & Control & 4.40 & - & * & * \\
\hline & $\begin{array}{l}\text { First } \\
\text { Experimental }\end{array}$ & 6.92 & - & - & - \\
\hline & $\begin{array}{l}\text { Second } \\
\text { Experimental }\end{array}$ & 7.44 & - & - & - \\
\hline \multirow[t]{3}{*}{$\mathbf{Q F}$} & Control & 1.88 & - & * & * \\
\hline & $\begin{array}{l}\text { First } \\
\text { Experimental }\end{array}$ & 6.20 & - & - & - \\
\hline & $\begin{array}{l}\text { Second } \\
\text { Experimental }\end{array}$ & 5.56 & - & - & - \\
\hline \multirow[t]{3}{*}{ Total } & Control & 27.12 & - & $*$ & * \\
\hline & $\begin{array}{l}\text { First } \\
\text { Experimental }\end{array}$ & 42.36 & - & - & - \\
\hline & $\begin{array}{l}\text { Second } \\
\text { Experimental }\end{array}$ & 43.84 & - & - & - \\
\hline
\end{tabular}


Results in Table (3) show that there is a statistically significant difference between the mean score of the control group $(m=27.12)$, the first experimental group $(m=42.36)$ and the second experimental group $(\mathrm{m}=43.84)$ in the post-test of the VLT which is significant at (0.01) level.

\section{Results Related to the Second Hypothesis}

Concerning the differences among the three groups, the researcher used t-test for dependent measures to verify the differences between each question and the total score in the prepost administration of the vocabulary learning test. Table 4 illustrated these results.

Table (4): Results of the t-test of the comparing the post administration of the vocabulary learning test to the control group

\begin{tabular}{|c|c|c|c|c|c|}
\hline Variable & Group & Mean & $\begin{array}{l}\text { Std. } \\
\text { Deviation }\end{array}$ & t-value & Sig. \\
\hline $\mathbf{Q A}$ & Pre & 8.64 & 2.36 & 0.14 & No sig. \\
\hline & Post & 8.56 & 2.08 & & \\
\hline QB & $\begin{array}{l}\text { Pre } \\
\text { Post }\end{array}$ & $\begin{array}{l}4.20 \\
3.92\end{array}$ & $\frac{1.77}{2.23}$ & 0.56 & No sig. \\
\hline $\mathbf{Q C}$ & Pre & 4.56 & $\frac{2.32}{.30}$ & 1.14 & No sig. \\
\hline QD & $\begin{array}{l}\text { Post } \\
\text { Pre }\end{array}$ & $\begin{array}{l}4.92 \\
3.56 \\
\end{array}$ & 2.08 & 0.63 & No sig. \\
\hline & Post & 3.80 & 2.10 & & \\
\hline$\overline{\mathbf{Q E}}$ & $\begin{array}{l}\text { Pre } \\
\text { Dost }\end{array}$ & 4.96 & 2.40 & 2.23 & 0.05 \\
\hline $\mathbf{Q F}$ & Pre & $\frac{4.04}{2.08}$ & $\frac{2.53}{2.08}$ & 0.72 & No sig. \\
\hline Total & $\begin{array}{l}\text { Post } \\
\text { Pre } \\
\text { Pet }\end{array}$ & $\begin{array}{l}\frac{1.88}{28.00} \\
27.00\end{array}$ & $\begin{array}{l}2.29 \\
9.41 \\
992\end{array}$ & 1.29 & No sig. \\
\hline
\end{tabular}

Table (4) indicates that there is no statistically significant difference between the mean score of the pre-post administration of the vocabulary learning test in the control group. This difference is not significant for the total score of the test. Also, this difference is not significant for all questions of the test except for $(\mathrm{QE})$ as $(\mathrm{t}$-value $=2.23$ ) which is significant at $\leq$ 0.05 level in favor of the post administration.

\section{Results Related to the Third Hypothesis}

Concerning the differences among the pre-post administration of the vocabulary learning test to the first 
experimental group, the researcher used t-test for dependent measures to verify the differences between each question and the total degree. Table (5) illustrated these results.

Table (5): Results of the $t$-test of the pre-post application of the vocabulary learning test to the first experimental group

\begin{tabular}{|c|c|c|c|c|c|c|c|}
\hline Variable & Group & Mean & $\begin{array}{l}\text { Std. } \\
\text { Deviation }\end{array}$ & $\begin{array}{l}\text { t- } \\
\text { value }\end{array}$ & Sig. & Eta $^{2}$ & $\begin{array}{l}\text { Effect } \\
\text { size }\end{array}$ \\
\hline \multirow[t]{2}{*}{$\overline{\mathbf{Q A}}$} & Pre & 9.48 & 0.65 & \multirow[t]{2}{*}{0.19} & \multirow{2}{*}{$\begin{array}{l}\text { No } \\
\text { sig. }\end{array}$} & \multirow[t]{2}{*}{-} & \multirow[t]{2}{*}{ - } \\
\hline & Post & 9.52 & 0.82 & & & & \\
\hline \multirow[t]{2}{*}{ QB } & Pre & 4.08 & 2.36 & \multirow[t]{2}{*}{6.32} & \multirow[t]{2}{*}{0.01} & \multirow[t]{2}{*}{0.62} & \multirow[t]{2}{*}{ Large } \\
\hline & Post & 6.64 & 1.38 & & & & \\
\hline \multirow[t]{2}{*}{$\overline{Q C}$} & Pre & 4.60 & 2.12 & \multirow[t]{2}{*}{6.65} & \multirow[t]{2}{*}{0.01} & \multirow[t]{2}{*}{0.65} & \multirow[t]{2}{*}{ Large } \\
\hline & Post & 7.28 & 1.40 & & & & \\
\hline \multirow[t]{2}{*}{ QD } & Pre & 4.28 & 1.92 & \multirow[t]{2}{*}{3.42} & \multirow[t]{2}{*}{0.01} & \multirow[t]{2}{*}{0.33} & \multirow[t]{2}{*}{ Large } \\
\hline & Post & 5.80 & 2.43 & & & & \\
\hline \multirow[t]{2}{*}{$\mathbf{Q E}$} & Pre & 4.88 & 2.48 & \multirow[t]{2}{*}{4.43} & \multirow[t]{2}{*}{0.01} & \multirow[t]{2}{*}{0.45} & \multirow[t]{2}{*}{ Large } \\
\hline & Post & 6.92 & 1.25 & & & & \\
\hline \multirow[t]{2}{*}{$\overline{\mathbf{Q F}}$} & Pre & 3.00 & 2.25 & \multirow[t]{2}{*}{8.35} & \multirow[t]{2}{*}{0.01} & \multirow[t]{2}{*}{0.74} & \multirow[t]{2}{*}{ Large } \\
\hline & Post & 6.20 & 1.22 & & & & \\
\hline \multirow[t]{2}{*}{ Total } & Pre & 30.32 & 8.27 & \multirow[t]{2}{*}{12.82} & \multirow[t]{2}{*}{0.01} & \multirow[t]{2}{*}{0.87} & \multirow[t]{2}{*}{ Large } \\
\hline & Post & 42.36 & 5.59 & & & & \\
\hline
\end{tabular}

This table shows that $t$-value ranged from (3.42-12.82) and these values are significant at 0.01 level in favor of the post administration except for (QA) as there no significant difference was evident.

Effect size was calculated using Eta square which ranged from (0.33-0.87) this may be due to using the Frayer Model in improving the pupils' vocabulary learning. The effect size was large.

\section{Results Related to the Forth Hypothesis}

Concerning the differences among the pre-post administration of the vocabulary learning test to the second experimental group, the researcher used t-test for dependent measures to verify the differences between each question and the total score. Table (6) illustrated these results. 
Table (6): Results of the $t$-test of the pre-post administration of the vocabulary learning test to the second experimental group

\begin{tabular}{|c|c|c|c|c|c|c|c|}
\hline Variable & Group & Mean & $\begin{array}{l}\text { Std. } \\
\text { Deviation }\end{array}$ & $\begin{array}{l}\mathrm{t}- \\
\text { value }\end{array}$ & Sig. & Eta2 & $\begin{array}{l}\text { Effect } \\
\text { size }\end{array}$ \\
\hline \multirow[t]{2}{*}{$\mathbf{Q A}$} & Pre & 8.76 & 1.76 & \multirow[t]{2}{*}{2.97} & \multirow[t]{2}{*}{0.01} & \multirow[t]{2}{*}{0.27} & \multirow[t]{2}{*}{ Large } \\
\hline & Post & 9.76 & .87 & & & & \\
\hline \multirow[t]{2}{*}{ QB } & Pre & 3.96 & 1.36 & \multirow[t]{2}{*}{9.32} & \multirow[t]{2}{*}{0.01} & \multirow[t]{2}{*}{0.78} & \multirow[t]{2}{*}{ Large } \\
\hline & Post & 6.72 & 1.48 & & & & \\
\hline \multirow[t]{2}{*}{$\mathbf{Q C}$} & Pre & 4.64 & 2.23 & \multirow[t]{2}{*}{5.83} & \multirow[t]{2}{*}{0.01} & \multirow[t]{2}{*}{0.59} & \multirow[t]{2}{*}{ Large } \\
\hline & Post & 7.12 & 1.23 & & & & \\
\hline \multirow[t]{2}{*}{ QD } & Pre & 4.64 & 2.69 & \multirow[t]{2}{*}{5.54} & \multirow[t]{2}{*}{0.01} & \multirow[t]{2}{*}{0.56} & \multirow[t]{2}{*}{ Large } \\
\hline & Post & 7.24 & 1.26 & & & & \\
\hline \multirow[t]{2}{*}{$\mathbf{Q E}$} & Pre & 4.00 & 2.25 & \multirow[t]{2}{*}{8.02} & \multirow[t]{2}{*}{0.01} & \multirow[t]{2}{*}{0.73} & \multirow[t]{2}{*}{ Large } \\
\hline & Post & 7.44 & 1.00 & & & & \\
\hline \multirow[t]{2}{*}{$\mathbf{Q F}$} & Pre & 1.92 & 1.65 & \multirow[t]{2}{*}{7.33} & \multirow[t]{2}{*}{0.01} & \multirow[t]{2}{*}{0.69} & \multirow[t]{2}{*}{ Large } \\
\hline & Post & 5.56 & 2.50 & & & & \\
\hline \multirow[t]{2}{*}{ Total } & Pre & 27.92 & 7.78 & \multirow[t]{2}{*}{15.84} & \multirow[t]{2}{*}{0.01} & \multirow[t]{2}{*}{0.91} & \multirow[t]{2}{*}{ Large } \\
\hline & Post & 43.84 & 5.69 & & & & \\
\hline
\end{tabular}

This table indicates that the second experimental group outperformed well as t-value ranged from (2.97-15.84) and these values are significant at 0.01 level in favor of the post administration of the VLT and this means that the Contextual Redefinition Strategy has a great effect on the pupil's performance.

The effect size was calculated using Eta square which ranged from (0.27-0.91) this may be due to the using of Contextual Redefinition strategy. This means that the effect of Contextual Redefinition strategy is significant and large.

Table (7): The Effect Size of Frayer Model and Contextual Redefinition strategy in the Pre-Post Test of the two Experimental Groups

\begin{tabular}{|l|l|l|l|l|l|}
\hline VLT & Group & Mean & t- value & Eta2 & Effect size \\
\hline \multirow{2}{*}{ Total } & Exp1. & 42.36 & 12.82 & 0.87 & Large \\
\cline { 2 - 6 } & Exp2. & 43.84 & 15.84 & 0.91 & Large \\
\hline
\end{tabular}

The results in table (7) indicate that t-value of the second experimental group (15.84) is higher than the t-value of the first experimental group (12.82). Moreover, Eta square of the second 
experimental group (0.91) is higher than the Eta square of the first experimental group (0.87).

This means that the two experimental group pupils outperformed the control group students but the second experimental group which was taught by using Contextual Redefinition strategy has a great effect on the pupils' performance than the first experimental group which taught by using Frayer Model.

Based on the above analysis, it can be stated that Contextual Redefinition strategy is more effective in enhancing vocabulary learning of second year preparatory school pupils. Then pupils are able to define different words according to many contexts.

\section{Conclusions}

With reference to the results of the study, the following points were concluded:

1. The current study provided evidence to the effectiveness of using Contextual Redefinition strategy and Frayer model in enhancing vocabulary learning.

2. Contextual Redefinition strategy and Frayer Model were effective in attracting pupils' attention, activating pupils' prior knowledge and experiences, actively involving pupils in the learning process of vocabulary, helping pupils to construct meaning, and demonstrating their learning.

3. Comparing the Contextual Redefinition strategy and Frayer model in maintaining and processing vocabulary results showed that Contextual Redefinition strategy enhanced pupils' performance better.

4. Contextual Redefinition strategy helped pupils in organizing new vocabulary, identifying it in many contexts and linking its form with its meaning in a way that made them perform well in the vocabulary learning test. 
Therefore, the current study proved the effectiveness of using Contextual Redefinition strategy in developing second year preparatory stage pupils' vocabulary learning more than Frayer Model and this was clearly showed in the statistical results.

\section{Suggestions for further research}

The following points are some suggestions for further research:

1. The effectiveness of using Contextual Redefinition strategy and Frayer model in developing different language skills.

2. This study can be repeated with other samples and settings at different levels of education and with a larger sample.

3. The effect of creating web quest projects and multimedia by using Contextual Redefinition strategy and Frayer model to enhance cooperative and collaborative learning for learners.

4. The effect of using Contextual Redefinition strategy and Frayer model on improving English language of learners with multiple intelligences.

5. The effect of using Contextual Redefinition strategy and Frayer model on improving students' thinking skills.

\section{References}

Abd Alkader, A. (2007). The Effectiveness of Instruction in Context Clues in Improving EFL Students Ability to Derive Word Meaning from Context and their Reading Comprehension. Journal of Psychological and Education Research, Faculty of Education, Menoufia University. 3(22). pp. 3-27. Available at:

http://0810giv30.1103.y.https.search.mandumah.com.mpl bci.ekb.eg/Download?file=lG0xcWWSieMP2/JYnI3l2LwQiq 8gxoZ0RPz3oN97/Rs=\&id=665043

Al Hussona, B. (2016). Investigating the Effect of Some Context Clues in Teaching Vocabulary on Iraqi EFL University Students' Achievement. Thi-Qar Magazine of Arts, College of 
Arts, Thi- Qar University, vol 20, pp. 89- 132. Available online at:

http://0810giuta.1103.y.https.search.mandumah.com.mplb ci.ekb.eg/Download?file=JNc35S+3HmIgq64MkXwNzxPAX ZjrfqOW6ku4TsSJNqM=\&id=866376

Al Neyadi. (2004). The Effects of Using Games to Reinforce Vocabulary Learning. Unpublished Doctorial Dissertation, Ain Women's College. Al Markaneya, AlAin.

Billmeyer, Rachel. 2003. Strategies to Engage the Mind of the Learner. Omaha, NE: Dayspring Press.

Cunningham, J. W., P. M. Cunningham, and S. V. Arthur. 1981. Middle and Secondary School Reading. New York: Longman.

Deighton, D. 1959. Vocabulary Development in the Classroom. New York: Bureau of Publications, Teachers College, Columbia University.

Febriyanto. (2010) The Effect of Frayer Model to Extend Students' Vocabulary of the First Grade at Smk Perbankan Riau. (A thesis, Faculty Islamic University of Riau, Indonesia, 2010) .

Frayer, D. A., Frederick, W. C., \& Klausmeier, H. J. (1969). A schema for testing on the concept mastery (Technical Report No. 16). Madison: University of Wisconsin Research and Development Center for Cognitive Learning.

Frey, N., \& Fisher, D. (2009). Learning words inside \& out: Vocabulary instruction that boosts achievement in all subject areas. Portsmouth, NH: Heinemann.

Graves. M (2007). Vocabulary Instruction in the Middle Grades. Voices from the Middle, 15, (1).

Greenwood, S. (2002). Making words matter: Vocabulary study in the content areas. The Clearing House, 75, 258-26

Greenwood, S.C., \& Flanigan, K. (2007). Overlapping vocabulary and comprehension: Context clues complement semantic gradients. The Reading Teacher. 61(3), 249-254. 
Gu, P. (2003). Vocabulary learning in second language: Person, task, context and strategies. TESL-EJ, 7(2). Retrieved October 3, 2006, from http://www-writing.berkeley.edu/ TESL-

EJ/ej26/a4.html

http://www.scholastic.com/parents/resources/article/you r-child-technology/understanding-interactive-learning.

Hulstijn, J.H., Theoretical and empirical issues in the study of implicit and explicit second-language learning, Studies in Second language Acquisition, 27, 129-140, 2005.

Kelley, J. G., Lesaux, N. K., Kieffer, M. J., \& Faller, S. E. (2010). Effective Academic Vocabulary Instruction in the Urban Middle School. The Reading Teacher, 64(1), 5-14. doi: 10.1598/RT.64.1.1

Khuwaileh, A. A. (1995). Words and context in EFL. Grazer Linguistics Student, 44, 27-36.

Kucan, L. (2012). What is most important to know about vocabulary?. Reading Teacher, 65(6), 360-366. doi:10.1002/TRTR.01054

Macceca, Stephanie (2007). Reading Strategies for Social Studies. United States of America: Shell Education.

Mardiyah, R. (2014). Improving Students' Vocabulary Achievement by Using Frayer Model. A Thesis. English Department. Faculty of Languages and Arts. State University of Medan.

Murphey, T., \& Arao, H. (2001). Reported belief changes through near peer role modeling. TESL-EJ, 5(3). Retrieved from

\section{http://wwwwriting.berkeley.edu/TESLEJ/ej19/a1.html}

Nagy, W., P. Herman, and R. C. Anderson. 1985. "Learning Words from Context." Reading Research Quarterly 20: 233-53.

Nahampun, E\& Sibarani, B (2014). The Effect of Using Frayer Model on Students' Vocabulary Mastery (A thesis, State University of Medan, Indonesia, 2014). 
Qasrawi, R. (2015). The Effectiveness of Using Context clues in Teaching English Vocabulary to English as a Foreign Language Learners. M.A Thesis. Faculty of Education, Birzeit University, Palestine. Retrieved from: https://search.mandumah.com/Record/702852

Rashidi, N., \& Soureshjani, K. H. (2011). The effect of teaching culturally-based texts on the Persian English as a foreign language (EFL) learners motivation and reading performance. Journal of Languages and Culture, 2(8), 141147.

Read, J. (2000). Assessing vocabulary. Cambridge: Cambridge University Press.

Schmitt, N. (2008). Instructed second language vocabulary learning, Language Teaching Research, 12, (3), 329-363.

Shatz, E. K., and R. S. Baldwin. 1986. "Context Clues Are Unreliable Predictors of Word Meanings." Reading Research Quarterly 21: 429-53.

Stahl, S. (2005). Four problems with teaching word meanings (and what to do to make vocabulary an integral part of instruction). In E. H. Hiebert and M. L. Kamil (Eds.), Teaching and learning vocabulary: Bringing research to practice (pp. 95-114). Mahwah, NJ: Lawrence Erlbaum. Retrieved August 18, 2009, from PsycINFO database.

Stahl, S. A., \& Kapinus, B. (2001).Word power: What every educator needs to know about teaching vocabulary. Washington, D.C.: National Education Association.

Sullivan, M. T. (2014). Using adapted Frayer model as graphic organizer for graph vocabulary. In N. Sonda \& A. Krause (Eds.), JALT2013 Conference Proceedings. Tokyo: JALT.

Tankersley, K. 2005. Literacy Strategies for grades 4-12: Reinforcing the threads of reading. Alexandria: Association for Supervision and Curriculum Development. 
Teacher Reseurce Guide (2006). Retrieved from Florida Center For Reading Research in http://www.fcrr.org/curriculum/PDF/G2-3/2-3TRG_2.pdf

Tierney, R. J., John. E. R., Ernest K. D. (1985). Reading Strategies and Practice. Fourth Edition. MA: Allyn and Backon

Wiese, Lee A. (2012). Analysis of Two Vocabulary Strategies: A study to indicate which strategy, Verbal and Visual Word Association or Contextual Redefinition, is best suited for transferring new words Graduate Faculty at the University of Wisconsin-Superior. Available online at: www.minds.wisconsin.edu/bitstream/handle/1793/63775 /Thesis\%20Com

WETA (2012). Classroom strategies retrieved from http://www.adlit.org/strategy library/ 